\title{
The Myth of the Inkarri: Colonial Foundations in International Law and Indigenous Struggles
}

\section{Elena Cirkovic}

Ph.D Candidate

Osgoode Hall Law School

York University

YCISS Working Paper Number 39

April 2006

The YCISS Working Paper Series is designed to stimulate feedback from other experts in the field. The series explores topical themes that reflect work being undertaken at the Centre. 
1572: Cuzco

With Tupac Amaru, four centuries of the Inca dynasty and nearly forty years of resistance in the Wilcabamba Mountains come to an end. Now the storms of war, the harsh rhythm of the conches, will no longer fall on the valley of Cuzco.

Eduardo Galeano, Memory of Fire, I. Genesis, 1982:76

\section{Abstract}

Past and present human rights violations have compelled indigenous peoples to seek effective remedies outside the states or territories in which they live. Increasingly, they adopt transnational discourses of human rights and combine them with local processes of reclaiming of indigenous cosmovisions and worldviews. One of the main goals pursued by indigenous people during the still ongoing $U N$ International Decade of the World's Indigenous People has been the revision of the UN Draft Declaration on the Rights of Indigenous Peoples for its eventual ratification by the General Assembly. Only 2 of the 45 articles in the Draft Declaration have been provisionally approved by the participating states. Both articles only affirm individual rights.

Since the promulgation of the Declaration of Human Rights, the United Nations (UN) has become a battleground for the ongoing struggle over the scope and content of an adequately inclusive human rights regime. The fight for recognition of indigenous peoples in international law, on which this research focuses, presents a formidable challenge to the universalizing mission of the UN. This is due to a continuing contestation between indigenous peoples and some states over the affirmation of indigenous peoples' legal status as "peoples", with a corresponding right to self-determination under international law, and the recognition of their collective rights as human rights. However, while international law appears to be providing some spaces for the dispossessed on the one hand, it continues on the other, albeit subconsciously, to bow its head to its very roots, which, as this paper will attempt to show, is inextricably, connected to the colonial encounter.

This paper questions whether the established human rights discourse can serve as a strategic tool for indigenous peoples, or if it is in fact working to delegitimize indigenous discourses and worldviews. Its exploration of indigenous rights and international law is part of a larger contemporary inquiry into the universalist aspirations of the public international legal system and the continued debate over the possibility of globally accepted human rights. Claims to universality of international law are regularly brought to negation or ignorance of its violent origins. Much of International Law's official history is the creation of rights among sovereign nations based on the idea that in time the legitimacy of a just order would work from the top down as it would from the bottom up. The origins of international law, however, are based on the exclusion and discrimination of the indigenous other as barbaric and incompatible with other legal addressees. This legacy casts its dark shadows on

\footnotetext{
${ }^{1}$ Galeano, Eduardo, Memory of Fire, I. Genesis. Norton and Company, 1985, p. 76.
} 
international law's claims to universality, because such universality would demand the inclusion of indigenous peoples as equal actors. In search of International Law's memory of its violent origins, this paper shall look to the existing, yet fragmented and often rejected narratives and memories of those that found themselves excluded in the creation of international law. This constitutes an act of decentring mainstream discourses and reviving indigenous memory of exclusion and oppression, which will contribute to a better understanding of international law's repressed memory of its own colonialist heritage. The objective is not to provide proposals for a reform of international law, but to outline conditions, which indigenous peoples encounter in the sphere of international law as they attempt to advance their claims.

\section{Introduction: Que dirian, cuando vuelva nuestro Inka?}

Inkarri's brother Espanarri cut off Inkarri's head... The highest mountains know. Inkarri's head is trying to grow towards his feet. The pieces of him will surely come together one day. On that day he will walk the earth followed by the birds.

Eduardo Galeano, Memory of Fire, I. Genesis, $1982^{2}$

Since the first moment of the encounter with the Spaniards, a choice between two alternatives became apparent to the diverse indigenous nations of the Americas: to accept or reject the conquest. The result of the second alternative is evident in the orally transmitted Andean narrative of the Inkarri. ${ }^{3}$ The title, Inkarri, comes from the Quechua pronunciation of Spanish words Inca Rey, or the Inka King. It tells the tale of the last Inka nobleman and rebel leader in Peru, Jose Gabriel Condorcanqui Tupac Amaru II (the 'Great Snake' in Quechua) and his followers who were taken to Cuzco, the capital of the Inka Empire, and summarily tried and executed for treason. On 18 May 1791, before a large gathering in the central square, Tupac Amaru II watched the hanging of his family members and execution of his wife Micaela Bastidias by garroting. After being tortured and then unsuccessfully drawn and quartered (his limbs could not be separated from his body by the horses employed), the rebel leader was beheaded. In the aftermath, the Spaniards unleashed a reign of terror against the Quechua people. The conquest had severed the head of the Inca, which ever since remained separated from the body; according to the story, when both come

\footnotetext{
${ }^{2}$ Ibid.

${ }^{3}$ Compiled by Peruvian anthropologist and novelist Jose Maria Arguedas in Arguedas, Jose Maria y Francisco Izquierdo Rios, Mitos, leyendas y cuentos peruanos. Lima: Ministerio de Educacion, 1947 and historian Alberto Flores Galindo in Flores Galindo, Alberto, Buscando un Inka: Identidad y utopia en los Andes. Magdalena: Instituto de Apoyo Agrario, 1987.
} 
together again, the period of disorder, confusion, and darkness initiated by the Europeans will end and the Andean people will recuperate their memory. ${ }^{4}$

Inkarri is a memory of a failed indigenous rebellion against the Spaniards and the centuries of darkness that ensued. The story recollects an instance of violence committed against a people. It also recollects the period in which the notion or a colonial narrative of 'indigenous' emerges, as the vanquished other, the subjugated, and the victim. The relationship between the colonizer and the colonized became a source of many debates in the sixteenth century among Spanish theologians and jurists, over the legitimacy of the Spanish invasion, as well as the legitimacy of indigenous rebellion against it. The hierarchical and discriminatory nature of colonial societies has been legitimized through philosophical understanding of the ontological asymmetry of human species. This was the moral, but also rational legitimization of the relation of domination within colonial societies and the colonial ethnocide.

The announcement of a possible revolution and reversal of the colonial order in narratives such as the Inkarri remained in the minds of the European colonizers as a potential violent disturbance to the newly established hierarchies, allowing them to resort to terror as a legitimate source of sovereign power and law. ${ }^{5}$ The terrible injustice of colonialism could be compensated only at the cost of transferring the fear of Indians to the whites. The modern jurisprudence, however, concealed the effects of colonial violence on those who suffer under the rule of law in the colonies. ${ }^{6}$ This history became a suppressed memory within the institutions and values of the international law; what remained was only its universal moralism. And in time, as far as the indigenous peoples could not escape this hegemonic political culture, they manipulated and appropriated it within the context of the emerging colonial system. The memory of violence, however, never disappeared; it remained guarded within the subconscious of a culture whose memory never forgot the details. ${ }^{7}$

This paper is divided into four sections. Section I discusses the colonial origins of international law, focusing on its structural grounding and the need to legitimate the violent invasion of the Americas. It looks at the sixteenth century debate among Spanish theologians and jurists, evaluating the legitimacy

\footnotetext{
${ }^{4}$ Indigenous identity becomes that of a victim or subversive, obscuring the multifaceted dimensions of indigenous mobilization. Current attempts at a universal definition of 'Indigenous' also impose limits on indigenous peoples' political, cultural, or economic aspirations. It emphasizes the status of being colonized and dominated, obscuring indigenous individual nationalities. It is important to note that the Spanish defeat of Tupac Amaru II, for instance, was assisted by other indigenous groups, who were subjugated by the Incas prior to the Spanish arrival. The association of indigenous peoples with a status of mere victims is easily complicated by these situations and alliances.

${ }^{5}$ Youngblood Henderson, James (Sakej), “The Context of the State of Nature," in Marie Battiste (ed.), Reclaiming Indigenous Voice and Vision. Vancouver: UBC Press, 2000, p. 11.

${ }^{6}$ Ibid.

${ }^{7}$ Derrida, Jacques, "Canons and Metonomies: An interview with Jacques Derrida," in Richard Rand (ed.). Logomachia, The Conflict of the Faculties. Lincoln and London: University of Nebraska Press, 1992.
} 
of Spanish conquest of the Americas and the extremity of violence waged against indigenous populations. Discourses that took place in the sixteenth century, concerned directly indigenous people's lives, but excluded them as equal interlocutors and questioned their place in the emerging international order. Section II observes briefly the evolution of international law through the nineteenth century positivism, culminating in the contemporary discourses of human rights. It examines how international law developed a contradictory notion that in order for order, progress and enlightenment to spread, violence, however extreme, would be needed to modernize the local peoples who did not want to be modernized. Section III observes the extent to which the contemporary international law has the capacity to recognize this contradiction and its colonial past through human rights discourse. It examines this question by focusing on the principle of self-determination. Section IV contains brief final conclusions.

\section{Indigenous Peoples and Development of International Law: Early Experiences}

To our father the creator Tupac Amaru:

Listen, my father, my Serpent God, listen

The bullets are killing; the machine guns are exploding the veins,

Iron sabres are cutting human flesh;

The horses, with their hoofs, with their mad and heavy skulls...

Here and in all parts

\section{Jose Maria Arguedas, $1984^{8}$}

Conquest of new lands was a primary concern of Europeans who arrived to South America in the sixteenth century, and few had sufficient preparation or interest to comprehend the challenges represented by the world they encountered. ${ }^{9}$ They did not recognize or understand the societies with organizational and recording traditions radically different from their own. Thus, for Spaniards who came from overseas "preoccupied with enriching themselves, securing honours, and evangelizing natives by force," $" 10$ the primary intellectual concern was finding new justifications for the invasion. An abyss then formed between the local peoples and the Spaniards, which to the present day continues to mark the most profound structural fission in the identities of postcolonial societies.

In his account of Latin American history, The Memory of Fire trilogy, Uruguayan novelist and journalist Eduardo Galeano writes, "Bad dreams, nightmares about abysses or vultures or monsters, may portend the worst. And the worst, here, is being forced to go to the Huancavelica mercury mines or to the

\footnotetext{
${ }^{8}$ Arguedas, Jose Maria, "Himno a Tupac Amaru," in Migel Angel Huaman (ed.), Poesia y utopia andina. Lima: DESCO, 1988, p. 65. [Translated by the author.]

${ }^{9}$ Rostworowski de Diez Canseco, Maria, History of the Inca Realm. Cambridge University Press, 1999, pp. 3-4. ${ }^{10}$ Ibid.
} 
far-off silver mountain of Potosi." In the Santa Barbara mercury mine located in Huancavelica, highland Peru, most of the forced indigenous labourers died swiftly as they produced what the Iberian conquerors sought above all, precious metals and free Indian labour needed for its extraction. ${ }^{12}$ Notably, the epicentre of the Tupac Amaru rebellion was in the area near Potosi mines. The new lands producing silver and gold revolutionalized the markets in Europe and launched the first stages of the modern era. In the period between 1520 and 1540 Peru and Mexico became the heartlands of the Spanish Empire, not only because of their rich mines, but also because of the large population of highland Indians. In response to violent patterns of exploitation, indigenous peoples did respond through both passive and active resistance. Tupac Amaru II launched the rebellion in response to the tightening of the oppression and particularly taxation and the labour draft to ensure a greater number of workers for mine owners. This massive and organized movement engulfed the entire southern Andes, ushering in an age of violent confrontations. Tupac Amaru became a historical symbol of waves of Indian rebellions and subsequent violent repressions, which continued to this day. Unless Indians were entirely subjugated, there would always remain a risk of war.

The legality if violence in the colonies came into question after its excessive nature shocked some of the Spanish missionaries. Not all colonizers arrived solely in search of gold, some arrived seeking souls for salvations. The atrocities committed against the natives by the Spaniards in the decades following 1492 prompted a famous sermon by Dominican friar Antonio de Montesinos in 1511 in which he dramatically urged the Christianization of the Indians and inquired: "Are these Indians not men? Do they not have rational souls?"13 This apparently astonished the colonists developing a public clash in the Americas between the zeal for propagation of the gospel and the greed for precious metals. ${ }^{14}$ The legitimacy of the conquest was to be determined through debates and discourses of Spanish theologians and jurists. Even at the beginning of colonization, which resulted in 90 to 95 percent depopulation of indigenous peoples overall in the Americas, ${ }^{15}$ Spanish scholars and jurists were concerned with the universality of the emerging law among nations. The bitter dispute that had raged in both Spain and the New World since the 1492, questioned the humanity of American natives and their capacity for the

\footnotetext{
${ }^{11}$ Galeano, Eduardo, Supra note 1 at p. 173.

${ }^{12}$ Dobyns, Henry and Doughty Paul, Peru: A Cultural History. New York: Oxford University Press, 1976, p. 122.

${ }^{13}$ Quoted in Hanke, Lewis, All Mankind is One: A Study of the Disputation Between Bartolome de Las Casas and Juan Gines de Sepulveda in 1550 on the Intellectual and Religious Capacity of the American Indians. Northern Illinois University Press, 1974, p. 4.

${ }^{14}$ Ibid.

15 Thornton, Russel, American Indian Holocaust and Survival: A Population History since 1492. Norman: University of Oklahoma Press, 1987.
} 
Christian religion and European civilization. ${ }^{16}$ These debates extended the mission of the Spaniards — in addition to looting and enriching themselves with gold and silver they now had a duty to indoctrinate the non-Christians. Thus, for the first time, a colonizing nation organized a formal inquiry into the methods used to extend its empire alongside an attempt to stigmatize an entire race as inferior. ${ }^{17}$

In 1532, Spanish theologian and jurist Francisco de Vitoria, set out the following propositions, which subsequently influenced the developing law of nations: (1) The difference between Indians and the Spaniards is rendered primarily along the lines of the respective differences of customs and social practices. (2) These differences can be overcome through his system of jus gentium and his understanding of Indians as possessing universal reason and therefore capable of understanding and being bounds by this universal law. Thus, Spanish claims to Indian land on the basis of 'discovery' or divine law, could not violate the inherent rights of Indian inhabitants. (3) If, however, the Indians transgressed these universally binding norms, for despite their possession of reason they were barbaric and uncivilized, the Spanish were justified in conquering and governing them "partly as slaves." 18 The conclusion was that it is precisely what denotes their different social and cultural customs and practices, that justifies the disciplinary measures of war, which would annihilate the Indian identity, and replace it with the identity of the Spanish. ${ }^{19}$ Natural and divine law therefore legitimized Spaniard's overlodrship and war against the "barbarians."

The precept of Vitoria's natural law came from the medieval scholastic theology of St. Thomas Aquinas. Thomist natural law could be applied to all rational beings (to all men that is), and could be ascertained through the observation of people's practices. ${ }^{21}$ Significantly, natural law ultimately cohered in Aquinas's notion of eternal law emanating from God. ${ }^{22}$ Consequently, the ultimate source of law remained rooted in the Christian God, as well as European notions of culture, family, and government. Thus, although Vitoria appears to be distancing himself from the Spanish claims on the basis of the

\footnotetext{
${ }^{16}$ Hanke, Lewis. Supra note 14.

${ }^{17}$ Quijano, Anibal, "Coloniality of Power and Eurocentrism in Latin America," (June 2000) 15 (2) International Sociology, pp. 215-232.

${ }^{18}$ De Vitoria, Francisco, Political Writings. Cambridge: Cambridge University Press, 1991, pp. 231-352 (3.8.18).

${ }^{19}$ Anghie, Anthony, "Francisco de Vitoria and the Colonial Origins of International Law," (1996) 5(3) Social and Legal Studies, pp. 321-336.

${ }^{20}$ For a more detailed account of influence of these debates on colonial Peru see Munarriz, Gerardo, A Comparative Analysis of the UN and OAS Failures to Positively Affect the Human Rights Situation in Peru. Master of Laws Thesis, North York, Ontario: York University, 2004.

${ }^{21}$ St. Thomas Aquinas, On Law Morality and Politics. William P Baumgarth and Richard J. Regan (Eds), Indianapolis: Hackett Publishing Company, 1988, pp. 19-20, 58-60.

${ }^{22}$ Fitzpatrick, Peter, Modernism and the Grounds of Law. Cambridge: Cambridge University Press, 2001, p. 155.
} 
divine law, his own precepts are deeply rooted in Christian thought. As Vitoria mentions, natural law encompassed all rational humanity, and included rights such as the right to travel, sojourn, trade, and proselytize in foreign lands. Indigenous peoples had to respond positively to Spanish arrival, because this was a part of some preceding consensus of among sovereign peoples. But in order to constitute a sovereign people they had to resemble the Europeans; otherwise they were non-sovereign. The indigenous peoples, not resembling the Spaniards, consequently entered a permanent situation of inclusion and exclusion in international law.

The discussion on legitimacy of colonialism continued to oscillate further between criticism and apology for colonial invasion in the debate between Bartolome De Las Casas and Juan Gines de Sepulveda. After witnessing brutalities in the Americas, de Las Casas argued for peaceful persuasion as the way to convert Indians to Christianity. His attempts to restrict Spanish activities in South and Central America enraged his opponents and resulted in an official dispute at Valladolid in 1550 with Sepulveda, who supported the war against the Indians. According to Las Casas, "If I should go to particularize the murders and slaughters committed in that region [Peru], the reader would find them so horrid and so numerous that in both respects they would far excel what have been said touching the other parts of India [the Americas]." ${ }^{.33}$ Apparently, "Emperor Charles V was so impressed by Las Casas' views on the sovereignty of the Indians over their lands that he had been disposed to abandon Peru on grounds of conscience, had not the famous Dominican theologian Francisco de Vitoria recommended otherwise."24 Sepulveda, however, was a fairly influential renaissance scholar and an Aristotelian, whose arguments had significant impact in Spain. Founding his arguments in Aristotle's theory of natural slaves, Sepulveda argued that "Spaniards have an obvious right to rule over the barbarians because of their superiority." ${ }^{25}$ Consequently, the nature of the Indians became involved in the kind of treatment to be accorded to them. It was the cultural differences between them and the Spaniards, what demarcated a vision of the sovereignty doctrine. Christian and civilized Spaniards could govern themselves and were sovereign, while the pagan Indios were not, and could be legitimately subjected to Spanish domination. Brief episodes of troubling conscience, which Las Casas exposed in his dramatic testimonies of brutalities in the colonies, became a blind spot in the emerging doctrines of natural law among sovereign nations.

\footnotetext{
${ }^{23}$ B. de Las Casas, The Tears of the Indias: Being an Historical and True Account of the Cruel Massacres and Slaughters of Above Twenty Millions of Innocent People Committed by the Spaniards in the Islands of the West Indies, Mexico, Peru, Etc. An Eye-witness Account written by B. de Las Casas, translated into English by John Phillips and Published in London in 1656. Baarle-Nassau: SoMa, 1980, p. 66.

${ }^{24}$ Hanke, Lewis, Supra note 17 at p. 61.

${ }^{25}$ De Sepulveda, Juan Gines, Democrates Segundo o de las Justas causes de la Guerra contra los indios. Edicion critica bilignue, traduccion castellana, por Angel Losada. Madrid: Instituto Francisco de Vitoria, 1951, pp. 38-43.
} 
Indigenous peoples were categorized as non-sovereign due to a variety of factors, including the need for imperial expansion and greed for gold and silver among Spaniards, who had for centuries been accustomed to an economy based to some extent on spoils of war wrested from the Moors. ${ }^{26}$ Between 1530 and 1650 alone, Spain received 181 tons of gold and 16,887 tons of silver from its colonies in the Americas. ${ }^{27}$ The enormous wealth created by mining fueled Spain's prosperity and early stages of industrialization. Economic gains were accompanied with ideas of universality (cultural and cognitive imperialism) and particularity (viewing the local as static and immutable), which emerged from Europeans' assumption that the native populations of the Americas were inferior peoples, and naturally born slaves. Fifteenth and sixteenth century theologians and jurists relied upon an interpretation of Aristotle's theory of natural slavery, as well his idea of man's natural quest for knowledge driven by 'wonder' to support their justification of colonial relations. As Canadian aboriginal scholar James Youngblood Henderson argues, "This quest for truth, universal values, and virtue informs the idea of the universal civilization and begins to explain why Europeans left their lands and went to such efforts to discover, as they thought, the whole world. ${ }^{28}$ The oppressor represented the universal model, while the dominated failed to develop and reach the higher stage in the civilization process.

The Spanish debate had established themes and concepts, which reinvented themselves at different stages in history of international law. The colonial encounter produced a new mental category to codify the relations between conquering and conquered populations: the idea of race as biologically structured, explaining not just physiognomic differences, but also the mental and cultural differences. ${ }^{29}$ Those relations of domination came to be considered as natural and legitimized through international law, which was formulated as a universal law based on natural law principles and found through human reason. With the colonization of the Americas, new material, subjective, and intersubjective relations were created alongside the emergence of the new Euro-centred, capitalist, colonial world power structure. Indigenous peoples occupied a lower status in this new universe as objects of study or domination, exploitation, and discrimination. All non-Europeans could be placed in relation to the Europeans in a linear revolutionary process from primitive to civilized, irrational to rational; in other words, from non-civilized to Europeanized or modernized. Thus the "vocabulary of international law, far from being neutral or abstract [became] mired in this history of subordinating and extinguishing alien

\footnotetext{
${ }^{26}$ Hanke, Lewis Supra note 24 at p. 4.

${ }^{27}$ Furtado, Celso, Economic Development of Latin America: Historical Background and Contemporary Problems, Second Edition, Cambridge: Cambridge University Press, 1978 p. 22.

${ }^{28}$ Youngblood Henderson, James (Sakej), Supra note 6.

${ }^{29}$ Ibid.
} 
cultures." ${ }^{30}$ Modernizing violence was justified as necessary in order to eliminate the opposite to all that was rational and enlightened-the irrational, archaic, mysterious, and violent. As Dipesh Chakabarty writes, this subjugating violence in the name of modernity became the "unreasonable origin of reason." 31

By the nineteenth century international law gradually dissociated itself from naturalist frameworks, and gave way to legal positivism. In response to the triumph of reason and science, European legal scholars tried to present their discipline in scientific terms, whereby the rules of international law were to be derived from observances of actual behaviour of sovereign states. Territoriality and sovereignty remained central to the existence of international law. Describing this John Westlake writes, "Without society no law, without law no society. When we assert that there is such a thing as international law, we assert that there is a society of states: when we recognize that there is a society of states, we recognize that there is international law." ${ }^{22}$ Thus those societies that were advanced enough to be sovereign constituted international law, and in turn international law existed to legitimize their existence and sovereignty. Those other societies, such as the societies of indigenous peoples, did not factor into this definition. The standards and categories, which applied to civilized European states, did not apply to peoples whose societal and political organization differed from European institutions. ${ }^{33}$

The new dilemma of international law was the oscillation between the priority of sovereignty and normative law; particularity and universality. ${ }^{34}$ The position of indigenous peoples, remained the same. The lack of civilization denied them the recognition of their right to self-governance. The discourse of rights referred to the rights of civilized nations to govern the non-European savage communities. If the notion of human rights occurred in a non-Western society, it was said to be entirely due to the diffusion of the Enlightenment ideas among them..$^{35}$ As Martti Koskenniemi explains, the credo of the universal applicability of this discourse could be described as follows:

I will accept you, but only on the condition that I may think of you as I think of myself. However, recognition of particularity may be an act of condescension, and at worst a

\footnotetext{
${ }^{30}$ Anghie, Supra note 20 at p. 333.

${ }^{31}$ Chakabarty, Dipesh, Habitations of Modernity: Essays in the Wake of Subaltern Studies. Chicago Press, 2002 , p. 28.

${ }^{32}$ Quoted in Anghie, Anthony, Imperialism, Sovereignty and the Making of International Law. Cambridge: Cambridge University Press, 2005, p. 47.

${ }^{33}$ Ibid. pp. 55-65.

${ }^{34}$ Kennedy, David, “A New Stream of International Law Scholarship,” (1989) 7(1) Wisconsin International Law Journal, p. 13.

${ }^{35}$ Koskenniemi, Martti, The Gentle Civilizer of Nations. Cambridge: Cambridge University Press, 2001, p. 55.
} 
prelude for rejection. Between the arrogance of universality and the indifference of particularity, what else is there apart from the civilized manners of gentle spirits? ? $^{36}$

The effort of international legal discourse was to uphold colonial and imperial forces denying the indigenous peoples the right and capacity to influence their own destinies as equal members of the international community. International lawyers of European empires viewed colonization as "a perfectly natural drive; just as ownership was a projection of the owner's person in the material world, colonial possession was an aspect of the healthy state's identity and self-respect." ${ }^{37}$

The inclusion of non-European natives was possible only insofar as they became assimilated within parameters of universal humanitarianism, abandoning their traditional institutions. Telling is a statement by renowned Peruvian writer Ricardo Palma in 1881 on the defeat of Peru by Chile in the War of the Pacific: "In my view, the main cause of the great disaster is that the majority of the Peruvian population is made up of a degenerate and abject race, that you were trying to dignify and ennoble. The Indian does not have the spirit of the motherland; he is a natural enemy of white and coastal men." ${ }^{38}$ The elimination of the Indian not only allowed for civilizing or ennobling of the population and nation building, but also for clearing up the lands they inhabited, which became a central focus of nineteenth century economic liberalism. The tension of this period occurs between the sanctity of sovereign state and liberal dream of world community. This community, however, still could not include those peoples, who when evaluated against the European standard of civilization remained in the state of savagery. The vision of a homogenous nation state, in combination with liberal economic policies of the nineteenth century, an imaginary society of supposedly sovereign and independent nation states, became the fundamental notion that marked contained independence of the nation state. In the same way, international law became exclusively an issue of relations between sovereigns, which were intrinsically contrasted to certain uncivilized others excluded from participation in international law.

Still, as in the times of Vitoria, humanitarian problems that accompanied colonialism remained. The humanitarian crises, however, could be solved "through the export of rational, public, law based administrative structures." ${ }^{\prime 39}$ International law thus elaborated and expressed "normative superior/inferior relations, conceptualized in terms of what is good (right) and what is bad (wrong), what is valid and what is not, and what works and what does not... Hierarchy, in other words, [meant] difference in normative

\footnotetext{
${ }^{36}$ Ibid. p. 515.

${ }^{37}$ Ibid. p. 109.

${ }^{38}$ Quoted in Munarriz Gerardo, Supra note 21 at p. 129.

${ }^{39}$ Koskenniemi, Martti, Supra note 37.
} 
light." ${ }^{40}$ Not very differently from what Vitoria argued, indigenous peoples remained outside of the regulation of international law, which operated only between sovereigns. At the same time, they participated as peripheral peoples who were to be conquered and civilized. In other words, as bearers of rights, indigenous peoples were excluded or simply ignored.

The very existence of the savage and dangerous 'other' required the institutionalization of subordination, and so indigenous peoples became the 'subversive' element in the emerging order of the community of sovereign nations. A contradictory relationship emerged between international law's universalism and the incommensurability of the Europeans and the colonized peoples. Indigenous peoples became delineated as essentially different, mysterious, and savage, who as such, posed a problem for the universal aspirations of international law. Yet, if indeed the indigenous were so different in his essence, assimilation would be an impossible or a difficult process. Assimilation would contradict the supposed immutable qualities of indigenous as possessing lower capacities for reason. Incorporating the indigenous would require that he possess certain faculties that equal those of the Europeans. The solution would then rest in elimination through violence and other means, such as cultural ethnocide. On the other hand is the assumption that all humanity was once savage, but while the Occidental civilization was able to supersede this pre-civil state other still non-civilized societies could not. The West ceased to have savagery in common with the other peoples, but at the same time it continued to seek universal norms through which to include the savage peoples into the world community.

In the twentieth century it finally transformed into the era of pragmatism and institutions. Relationships created with colonialism translated into the language of law, while the actual histories became sanitized or retold as events of a far away past, which international law was apparently capable of overcoming with the advent of twentieth century human rights discourse.

\section{The Age of Human Rights and Indigenous Peoples}

We are the victims of genocide in the most terrible and explicit meaning of that idea. Yet some of us have survived and are still here, along with the States that perpetrated these crimes against us. The world knows that the sovereignty, legitimacy, and territorial integrity of these states is tainted and fundamentally impaired because of the unjust, immoral, and murderous means employed in their establishment upon indigenous lands. How can a thief go about establishing legal and legitimate possession of his stolen spoils? This, in reality, is the difficulty, which confronts the States-a difficulty which is compounded by the fact that some of the victims continue to walk about and remind everyone not to forget what was done.

Chief Ted Moses ${ }^{41}$

\footnotetext{
${ }^{40}$ Koskenniemi, Martti, "Hierarchies in International Law: A Sketch," (1997) 8(4) European Journal of International Law. p. 4.

${ }^{41}$ Moses, Ted, "Statement by Ambassador Ted Moses on behalf of the indigenous peoples of the North American Region to the World Conference on Human Rights," Vienna, 14-25 June 1993. Available at: http://www.dialoguebetweennations.com.
} 
With the advent of the human rights discourse, some indigenous peoples have accepted the language of international law, with hope that their claims will be addressed and understood. As Patrick Thornberry writes, "This illustrates a fundamental ambiguity that flows through historical discourses and principles-the universalizing discourse of law and right is form of imperialism; the law that oppresses, promises liberation." ${ }^{\prime 2}$ The colonial relationships reached a new stage with discourse of human rights, which not only claimed universality, but also seemed to give agency to previously marginalized populations.

However, the universalization of a juridical order based on precept which affirmed basic and inviolable dignity of human life, owed its existence to the enormous impact of a universal cultural event: the memory of the Second World War. While massacre as an event was not a novelty, what was novel was that in the last part of the twentieth century juridical institutions of universal pretenses have formalized a particular moral memory of the atrocities committed during the Second World War. The UN Charter Preamble includes a specific reference to wars that ravaged the western world in the twentieth century. ${ }^{43}$ The "untold sorrow of mankind" mentioned in the Preamble refers to this particular moment in history and not any such previous experience, including the colonial violence. The promotion of victorious states of an ambitious program of juridificaiton of state obligations, limited the previously sacred principle of state sovereignty. ${ }^{44}$ What legitimated the international law in twentieth century, and appeared to position it against the early civilizing missions, was its repudiation of direct colonialism, delegitimation of openly racist language, and establishment and recognition of the norm of selfdetermination. The reforms of the modern international law have made colonialism illegal and provided grounds for social forces to further alter or even reverse the direction of international law where it concerns the indigenous peoples today. The purpose of these reforms was to prevent an escalation of the conflict, considering the growing unrest in the colonial territories. It appeared that the role of international law was to uphold human rights norms and that the indigenous peoples could for the first time seek a space in international law, which would accept their grievances as legitimate. To what extent, however, did the new discourse of human rights differ from Natural Law and Civic Humanism of the sixteenth century, which was at the same time the other face of European colonialism? While the legacy of colonialism in international law did not vanish, the discourse of human rights now appeared as a sufficient and legitimate tool for marginalized peoples to advance their claims.

\footnotetext{
42 Thornberry, Patrick, Indigenous Peoples and Human Rights. Manchester: Manchester University Press, 2002 , p. 63.

${ }^{43}$ The Preamble begins with, "We the People of the United Nations Determined to save succeeding generations from the scourge of war, which twice in our lifetime has brought untold sorrow to mankind..."

${ }^{44}$ Gonzalez, Eduardo. "La Globalizacion del Derecho a la Verdad" in Memorias en conflicto: Aspectos de la violencia politica contemporanea. Belan, Raynald et al. (Eds) Lima: IEP, IFEA, 2004.
} 


\section{Question of Indigenous Self-Determination}

Beneath all the talk of human rights and their universal applicability, the ambiguousness of the principle of self-determination illuminates the fundamental contradictions of international law — its legitimation of colonial violence, contrasted with normative pretences and ambitions. Self-determination, if it were to take on its proper meaning, ${ }^{45}$ would undermine the essential principle on which international law was founded, the existence of sovereign nation states. Here, however, re-emerges the question of who creates and defines norms and principles of international law, and in whose language. If indigenous peoples are peoples, their right to self-determination would be undeniable in accordance with international law and as such, could potentially endanger the unity of existing sovereign states. If, however, they are not peoples, as some states claim, they have no such right, and remain non-sovereign, just as Vitoria explained over 400 years ago.

Because of the domination of settler states in the international system, the legal principle of selfdetermination and the process of decolonization became applied only in the context of state-to-state relations in the post war period. As Antonio Casesse argues, one of the legal modes of acquisition of territory under the classical international law included colonial conquest. ${ }^{46}$ Thus "the new law of selfdetermination has not resulted in the invalidation of these legal bases of title ipso facto." ${ }^{\prime 7}$ The so-called "blue-water doctrine" did not include the forms of internal colonialism practiced in countries with significant indigenous populations. The UN Charter did not provide specific definitions for what selfdetermination actually means, or which groups constitute a 'peoples. ${ }^{98}$ The UN General Assembly was leaning towards accepting whole colonial territories as subjects of self-determination. Consequently, in

\footnotetext{
${ }^{45}$ The content of this meaning is taken from Article 1.1 of ICCPR, "All peoples have the right of self-determination. By virtue of that right they freely determine their political status and freely pursue their economic, social and cultural development."

${ }^{46}$ In the Canadian and United States jurisprudence even judgments which affirm indigenous territorial rights and recognize their prior existence as independent nations, affirm the right of the federal government's (in the case of the US) or the Crown's (in Canada) exclusive rights to regulate relationships with indigenous peoples, thus recognizing the colonial state's sovereignty over indigenous lands and peoples. See for example 1832 US supreme court decision for Worcester v. Georgia 31 US 515 (1832). The Supreme Court of Canada has said that Aboriginal rights were recognized and affirmed in the Canadian Constitution in 1982 in order to reconcile Aboriginal peoples' prior occupation of Canada with the Crown's assertion of sovereignty. On this topic see McNeil, Kent, "Reconciliation and the Supreme Court: The Opposing Views of Chief Justices Lamer and McLachlin," (2003) 2 Indigenous Law Journal, p. 1-25.

${ }^{47}$ Cassese, Anthony, Self-Determination of Peoples: A Legal Reappraisal. Cambridge: Cambridge University Press, 1995.

${ }^{48}$ Charter of the United Nations, 1 United Nations Treaty Series xv1; (1946).
} 
the post Charter assessment of its contents, indigenous peoples were not considered in the provisions of non-governing territories in Chapter XI. ${ }^{49}$

In the wake of the collapse of communism, the rise of new form of nationalism and secessionist movements in the 1990s resulted in a new quest of international lawyers and scholars who began to investigate how to better accommodate ethnic and national identities. The role of international law and its responsiveness to this situation came into question, including the viability of self-determination as a legal norm. The debates over whether the norm of self-determination should be broadened to accommodate this new situation, however, continued to deny the colonial context of its foundations. Law is seen as a responsive mechanism, which should either adjust to the current situation of post-cold war secessionist movements, or resist any negotiation, which would threaten to undermine what Westlake deemed as the basis of international law's existence, the very concept of statehood. ${ }^{50}$ What remains absent is the mystifying space outside of law, the moment in which it was formed. ${ }^{51}$ The notion of selfdetermination of indigenous peoples inevitably refers to some reversal of the colonial process, and sows the fears of secession and destruction of existing settler states. For this reason, far from changing drastically the position of indigenous peoples in international law, human rights discourse with its limits outlined by its cultural, political, or historical origins, only reaffirmed their absence from international law as equal actors.

For some settler-states indigenous claims to self-determination have been equated with violent secession movements in the Balkans, and as threats of violence for the creation of new statehood. ${ }^{52}$ The colonial violence became veiled behind the debates on self-determination which continued to analyze its threat to international peace and stability, and the capacity of international law to change and accommodate to these new threats. The colonial processes, through which indigenous peoples came to be denied their independence, became repressed in memory of international law. This is particularly evident in the way in which indigenous peoples are portrayed in literature on self-determination: as minorities or as peoples who have largely assimilated into the greater society. ${ }^{53}$ Some critical legal scholars warn

\footnotetext{
${ }^{49}$ Thornberry, Patrick, Supra note 42 at p. 92.

${ }^{50}$ On self-determination see Franck, Thomas, Fairness in International Law and Institutions. Oxford: Oxford University Press, 1995.

${ }^{51}$ Derrida, Jacques, "Force of Law: The "Mystical Foundation of Authority"," (1990) 11 Cardozo Law Review, p. 921.

${ }^{52}$ Cojti Cuxil, Demetrio. "Gobernabilidad democratica y derechos indigenas en Guatemala," in Sieder Rachel (ed.) Guatemala after the Peace Accords. University of London, 1998, p. 148.

${ }^{53}$ Franck, Thomas, Supra note 50 at p. 145.
} 
against an increasingly multiplying number of categories to cover distinctive cases. ${ }^{54}$ It appears that the colonization process has been completed. For indigenous peoples, however, an addition of the 'fourth world ${ }^{55}$ category is useful to specify that indigenous peoples remain at the periphery within third and first world alike.

The observance of indigenous self-determination as a threat to national or international security by some states unravels the problem in international law of the need for order, as well as the need for change. However the need for change is evident even in more mainstream theory on contemporary international law. Thomas Franck's emphasis on fair processes as means to just outcomes, results in his emphasis of the importance of a right to democratic government, which, "while not yet fully encapsulated by law, is now rapidly becoming a normative rule of the international system." ${ }^{56}$ In a sense, selfdetermination then becomes a source of democratic government "self-determination is the historic root from which the democratic government grew." ${ }^{, 57} \mathrm{He}$, however, does not endorse a more permissible external right to self-determination than is already permitted by the colonial model. Franck argues for national systems of government which prove their validity with established rules and processes which legitimize their governance. In discussing the possibility of extending the application of the law of selfdetermination he gives the example of minorities who have been denied political and social equality and the opportunity to retain its cultural identity. ${ }^{58}$ Here, a tension begins to emerge in his argument for, on the one hand, Franck disapproves of the separatist agenda, which he associates with 'post-modern tribalism' but on the other, his broader moral framework leads to the conclusion that international lawyers should find more appropriate responses to these nationalist claims by way of fairness discourse which in turn may lead to a deconstruction of the colonial model and to the possibility of a right of secession for groups denied the opportunity to retain their cultural identity.

The assertions to the right of self-determination are diverse and vary from nation to nation. Indigenous movements for restoration of their autonomous power and cultural integrity are in some cases

\footnotetext{
${ }^{54}$ Chimini, B.S, “Third World Approaches to International Law: A Manifesto," in Anghie, Anthony et al. (Eds.) The Third World and International Order. Leiden, Boston: Martinus Nijhoff Publishers, 2003, pp. 49-50.

${ }^{55}$ Fourth World is a term first used by Chief George Manuel and Micheal Posluns in their book The Fourth World: An Indian reality. New York: The Free Press, 1974. It refers not only to a geopolitical positioning of Indigenous nations which was separate from the first and Third World Blocs but also to a Hopi prophecy about the people climbing up though the worlds to this current one we live in - the Fourth World. Since that time the term has come to be widely used and we have expanded the paradigm further to talk about the Fifth World — which is the world of the refugee and the displaced persons. In times of discourse focused solely on development and trade at the international level these terms are important ways to remind ourselves of the need for active political analysis.

${ }^{56}$ Franck, Thomas, Fairness in International Law and Institutions. New York: Oxford University Press, 1995, p. 84.

${ }^{57}$ Ibid. p. 91.

${ }^{58}$ Ibid. p. 160.
} 
founded on the ideology of Native nationalism and rejection of models of government rooted in European cultural values. Reclaiming their space is thus a crucial component of current indigenous claims and healing processes. As Alfred Taiaike Gerald, a Kahnawake Mohawk scholar describes, an important part of healing ceremonies is to advance the development of "a powerful and unifying rationality to help us overcome the evil of colonization that haunts our lives." 59 One of the steps is reclaiming the space, nationhood, or community as a whole and asserting control over indigenous land and life. As Taiaike argues 'Part of the problem now is that our space hasn't been respected, that we've had structures and ideas imposed on us. We need to reclaim our intellectual, political, and geographic space. ${ }^{\circ 60}$ At present, indigenous peoples practice politics in the context of state law, or at best, international human rights law. Even if they succeed in achieving some of their goals, such as self-government, the basic power structures remain intact.

\footnotetext{
${ }^{59}$ Alfred, Taiaiake Gerald, Peace, Power, and Righteousness: An Indigenous Manifesto. Oxford University Press, 1999, p. xxi.

${ }^{60}$ Ibid.
} 


\section{Self-Determination as a Human Right}

The current impasse reached at the United Nations regarding the indigenous peoples' right to selfdetermination and its inclusion in the Draft Declaration of the Rights of Indigenous Peoples, is a result of the apparent failure to reconcile the discord between indigenous demands and human rights institutions, which were not created with indigenous peoples in mind as equal actors. The human rights covenants and other international instruments declare that 'peoples' have the right to self-determination. The preamble of the United Nations Declaration of Human Rights asserts that "Whereas it is essential, if a man is not to be compelled to have recourse, as a last resort to a rebellion against tyranny and oppression, that human rights should be protected by the rule of law" and "All human beings are born free and equal in dignity and rights." ${ }^{\prime} 1$

The right to self-determination emerges within contemporary human rights framework of international law, rather than the traditional Statist framework. More explicitly, right of selfdetermination is included in common Article 1 of the International Covenant on Civil and Political Rights (CCPR $)^{62}$ and Covenant on Economic, Social, and Cultural Rights (CESCR). ${ }^{63}$ Article 1 does not create the right to self-determination, but confirms that it already exists and in possession of all 'peoples. ${ }^{96}$ In essence, self-determination means that individuals and groups are free to make meaningful decisions about matters from all spheres of life. Indigenous peoples have proposed that the UN Draft Declaration of the Rights of Indigenous Peoples incorporate a version of common Article 1 (1) of the ICCPR and the CESCR, modified by changing the opening word from 'All,' to 'Indigenous,' so as to state that the right to self-determination belonged to indigenous peoples. The Article 3 of the Draft Declaration states that, "Indigenous peoples have the right to self-determination. By virtue of that right they freely determine their political status and freely pursue their economic, social, and cultural development." ${ }^{95}$ Representatives of many member states strongly opposed this motion, stating that these groups are not 'peoples' and have no international law to self-determination. The member states did not want the ' $s$ ' on peoples because it will mean that indigenous peoples will have collective rights, clearly undermining state control of lands and resources.

\footnotetext{
${ }^{61}$ Universal Declaration of Human Rights, General Assembly Resolution 217 A (iii), Adopted 10 December 1948.

${ }^{62}$ International Covenant on Civil and Political Rights (CCPR), (1966) 999, United Nations Treaty Series 171, in force 3 January 1976.

${ }^{63}$ International Covenant on Economic, Social, and Cultural Rights (CESCR), 993, United Nations Treaty Series 171, in force 23 March 1976.

${ }^{64}$ Moses, Ted, "Self Determination and the Survival of Indigenous Peoples," in Pekka Aikio and Martin Scheinin (eds.), Operationalizing the Right of Indigenous Peoples to Self-Determination. Turku, Finland: Institute for Human Rights, Abo Akademi University, 2000, pp. 155-178.

${ }^{65}$ Draft Declaration on the Rights of Indigenous Peoples, Revised Working Paper Submitted by the Chairperson/ Rapporteur, Mrs. Erica-Irene Daes, E/CN.4/Sub.2/1993/26.
} 
This ambiguity of terminology has been the source of endless debates in the international human rights system, trying to determine what constitutes a 'people' and who has the right to self-determination. General practice in traditional international law since 1945 affirms those entities that qualify as peoples with a corresponding right to self-determination are either tied to some objective criteria linked to ethnicity or historical sovereignty, or an aggregate population of a state or "one that is entitled to become a state. ${ }^{96}$ People are an entity that a priori has attributes of sovereignty or statehood. In order to accommodate indigenous claims to self-determination, the existing international law system would have to re-define and expand this practice.

By virtue of its inclusion in important international treaties, self-determination is a human rights norm that already exists in international law as a part of general or customary law. It also exists in relevant practices, which include discourses and action by which claims are presented in the name of self-determination, and by which authoritative responses to those claims are made. ${ }^{67}$ Indigenous peoples are thus appealing to a certain set of values of perceived universal applicability and norms that denote the way things should be for all humanity.

While the human rights regime reflects the 'normativity' of law, the development of rights implies that something is to be protected by some authority, and a violation of that right remedied accordingly. It then becomes defined and delimited by authoritative definition of that right, which is inevitably hierarchical and political. Indigenous peoples gain legitimacy through their activism use of human rights principles, and proper channels of existing national and international legal institutions. Rights discourses presuppose an existence of democratic institutions as well as their accessibility to potential claimants. Legitimacy of a particular struggle is evaluated through the lens of accepted institutional language. Right to self-determination becomes delimited by the existing authority of international legal institutions, which define, narrow, or broaden its scope. Undoubtedly there are 'pressures from below,' violent or peaceful secessionist movements, lobbying of non-governmental organizations and such, but how decisions are made within international institutions is limited by their ultimate goal and purpose. And what is the ultimate goal and purpose of the UN? The UN Charter, does not only concern itself with protection of human rights, but also with humanitarian intervention and territorial administration. The United Nations might offer space for resistance against imperialism, but at the same time it remains a tool for imperialism as a "manager of problems in the developing world." The colonial relationships between international law and the 'developing' world remain present not just

\footnotetext{
${ }^{66}$ Anaya, James, "Self-Determination as Collective Human Rights under Contemporary International Law," in Pekka Aikio and Martin Scheinin (Eds.), Operationalizing the Right of Indigenous Peoples to Self-Determination. Turku, Finland: Institute for Human Rights, Abo Akademi University, 2000, pp. 4-18.

${ }^{67}$ Ibid.

${ }^{68}$ Orford, Anne, “The Gift of Formalism,” European Journal of International Law 15 (2004), p. 188.
} 
as a matter of history, but as a current reality. ${ }^{69}$ Marginalized groups thus remain in a position where they hope to ameliorate their situations through an instrument that does not recognize them as equal actors.

\section{Declaring Indigenous Rights in International Law}

While some countries were celebrating five hundred-year anniversary of the colonial discovery in1992, the indigenous peoples of the Americas organized the First Continental Meeting of Indigenous Peoples on 500 Years of Indian Resistance in Quito, Ecuador. Indigenous peoples have referred to this encounter as a realization of the prophecy stating that fragmented indigenous nations, the Condor of the South, and the Eagle of the North, will come together again. The increasing indigenous organizing on the international level has resulted in consistent lobbying and struggle for indigenous land and resources, with some, albeit limited success. ${ }^{70}$ United Nations have become yet another combat zone between indigenous peoples and successive invading waves of European forms of life and thought. The adoption of the UN Draft Declaration on the Rights of Indigenous Peoples has been an important concern for indigenous peoples, as the UN Decade of the World's Indigenous People approached its end. The goal stated at the outset of the Decade was quite ambitious: to strengthen international cooperation for the solution of problems faced by Indigenous peoples in the areas of human rights. However, since 1995 only two articles out of the Draft's forty-five articles have been approved. As the indigenous representatives recently stated:

Brothers and sisters, we are in this great house but it is not our house. We are in a palace where documents are written for Peoples but not for our Indigenous Peoples. They open doors for us to enter but they close their ears and hearts. What can we do? We can do many things, even a hunger strike. ${ }^{71}$

The Decade ended with the failure of efforts to see the Draft Declaration adopted by the Human Rights Commission, questioning whether any gains have been made in pursuit of Indigenous selfdetermination at an international forum. In response, indigenous people's representatives at the UN initiated a hunger strike, which ended after a negotiation with representatives from the UN Commission for Human Rights, and a promise for future developments regarding the Draft Declaration.

In past three decades, representatives of indigenous peoples increasingly sought to engage with international law and institutions. Still, long before UN designated the Indigenous Decade, indigenous

\footnotetext{
${ }^{69}$ This topic has been the subject of recent critical scholarship on international law. See, Anghie, Supra note 32.

${ }^{70}$ In the Inter-American System, the most successful case has been the Awas Tigni v. Nicaragua case, where the Commission and the Court ruled in favour of the local indigenous community. See the Court Judgment No. 79, the Case of the Mayagna (Sumo) Awas Tingni Community v. Nicaragua of 31 August 2001, Available at: http://www.oas.org.

71 "End of the Indigenous Hunger Strike at the United Nations," 2 December 2004, Mapuche International Link News. Available at: http://www.mapuche-nation.org.
} 
peoples have been active in protecting their ancestral homelands and using whatever means necessary to ensure their survival, including legal channels and global forums. ${ }^{72}$ Indigenous peoples first attempted to liaison with the international community in 1923 when Cayuaga Chief Deskaheh of the Haudenosaune (the Iroquois Confederacy, still present and the oldest example of a 'League of Nations') petitioned the League of Nations through the good offices of the Government of the Netherlands. Then as now, indigenous peoples were met with indifference, and Chief Deskaheh was not allowed to speak. ${ }^{73}$

These recent events are an accumulation of long standing indigenous struggles. In the twentieth century, indigenous movement gained significant prominence in the 1960s and 1970s. Its rapid growth coincided with independence struggles, decolonization process, Cold War violence, as well as the growing human rights movement within the UN. The first international conference on non-governmental organizations (NGOs) on indigenous issues, the NGO Conference on Discrimination against indigenous Populations, was held in Geneva in 1977. In the same year, the International Indian Treaty Council gained consultative status with the UN Economic and Social Council (ECOSOC), the first indigenous organization with rights of participation in UN meetings. Especially, since the formation of the Working Group on Indigenous Populations in 1982, the UN became an important site of struggle for indigenous rights. Indigenous peoples went to the international community, because there was no other place to turn. They exhausted all remedies within the states, which were implementing, especially in South and Central America, extensive genocidal policies. As Ted Moses writes, "we viewed the opportunity to bring the concerns of the Indigenous peoples to the United Nations very seriously, for it offered a hope of a brandnew, and badly needed, means of redress for our people." ${ }^{74}$

The Working Group had two essential mandates: to review current developments on the promotion and protection of the human rights and fundamental freedoms of indigenous peoples, and to draft international standards to protect the rights of indigenous peoples. Members of the Working Group were cautioned not to hear complaints from Indigenous representatives. States that were behind serious gross and systematic human rights violations were sensitive about claims being made before the United Nations. The Working Group was positioned at the margins of the UN System, as a branch of the SubCommission on Prevention of Discrimination and Protection of Minorities. ${ }^{75}$ It took several years to convince the members of the sub-commission that indigenous peoples did not belong to same category as minorities, and that in some countries they still constitute the majority of the population.

\footnotetext{
${ }^{72}$ Alfred, Taiaiake Gerald and Jeff Corntassel, “A Decade of Rhetoric for Indigenous Peoples," 12 January 2004, OGIEK. Available at: http://www.ogiek.org/news.

${ }^{73}$ Ibid.

${ }^{74}$ Moses, Ted, “Invoking International Law”, in Marie Battiste (ed.), Reclaiming Indigenous Voice and Vision. Vancouver: UBC Press, 2000, p. 174.

${ }^{75}$ Ibid. p. 175.
} 
In order to create an ongoing UN mechanism for indigenous peoples a Permanent Forum on Indigenous Issues was established in 2000 by the UN Economic and Social Council (ECOSOC). The forum was compromised from a start. In addition, appointed indigenous and government representatives attending the inaugural meeting, argued that the Forum should function in support of research-policy making in relation to indigenous peoples, and not a site of complaints and political debate in reference to the contentious meetings of the Working Group in Geneva. As it stands, the Forum has no formal recourse for Indigenous peoples to remedy human rights violations in their communities. ${ }^{76}$ The Indigenous delegates have only about three minutes to report the needs of their communities under the pre-determined discussion topics, such as 'health' or 'environment.' As Taiaiake and Corntassel write:

Given its serious limitations in addressing or acting on the blatant injustices and continuing genocide perpetrated against 370 million indigenous peoples worldwide, structuring the Permanent Forum to function solely as an internal report writing and data gathering agency for state policy circles is tantamount to an act of criminal negligence on the part of the UN. ${ }^{77}$

In the 1980s and 1990s, the Working Group drafted the Declaration on the Rights of Indigenous Peoples, which was the result of persistent lobbying since the Working Group's formation. After twelve years of debate, a broad consensus was reached among the UN human rights experts and the Indigenous partners on a proper interpretative declaration, which articulates forty-five articles that set minimum standards for indigenous people's human rights. This process witnessed collaboration between technical experts and indigenous people. It also became a set of aspirations of postcolonial self-determination and human rights. As Youngblood Henderson states, "We argued that Indian peoples are peoples under the charter and covenants. The declaration is an interpretive tool for applying UN Human Rights Covenants to Indigenous peoples and to begin a belated design for post-colonial nation-building." 78 The assumption which underlines the declaration was stated in the preamble, which affirms "that Indigenous peoples are equal in dignity and rights to all other peoples, while recognizing the right of all peoples to be different, and to be respected as such." 79 Besides the dramatic claim that indigenous peoples enjoy a right of self determination, the Draft Declaration demands among other things that States observe a range of collective rights, protect the peoples from genocide and ethnocide, respect indigenous citizenship, restore and protect the environment, and the like. The text also connects self-determination to autonomy, but only as a specific and not exclusive form of exercise of self-determination. It describes that "rights

\footnotetext{
${ }^{76}$ Alfred, Taiaiake Gerald and Jeff Corntassel, Supra note 55.

${ }^{77}$ Ibid.

${ }^{78}$ Youngblood Henderson, James (Sakej), "Post Colonial Ghost Dancing," in Marie Battiste (ed.), Reclaiming Indigenous Voice and Vision. Vancouver: UBC Press, 2000, p. 169.

${ }^{79}$ Supra note 62.
} 
recognized herein constitute the minimum standards for survival, dignity, and well-being of the indigenous peoples of the world." ${ }^{\prime 0}$ By principle of equality in international law, indigenous peoples reserve their right to independent statehood, if it becomes necessary in extreme cases.

Significantly, the work of indigenous peoples and the Draft Declaration is based on their continuous experience of human rights abuses. They did not rely on "the theory or hypothesis about international law and international rights. There was nothing abstract about [their] work." ${ }^{81}$ In a way, the introduction of particular experiences of indigenous peoples into the arena of international law signified an attempt to include different forms of understanding and knowledge, based on indigenous experiences, cosmovision, or interpretation. The voices of indigenous peoples have for the first time entered the international arena as directly articulated by their leaders and representatives rather than though particular theory of international law or rights. But it is precisely this nature of the Declaration that differentiates it from other instruments at the $\mathrm{UN}$, and deviates from the formal language employed within the institution. Despite their participation, it is not clear that indigenous arguments and claims are recognized by their audiences. In the arguments on self-determination, it becomes evident that what their idea of what self-determination means is quite different from the visions of State representatives or some UN officials.

What this implies for indigenous peoples is that while they are fundamentally affected by the way the right to self-determination is constituted in international law, they are not necessarily included in the process of its interpretation. Indigenous lobbying at the Working Group demonstrates indigenous participation in the making of the Draft Declaration, but true consideration and respect for their perspectives is limited. Over its history, international law has constructed a particular meaning of indigenous identity and entitlement. This is not consistent with the self-image of indigenous peoples as nations. The accepted model of law and legal reasoning depends on how and institution such as the UN views itself, and what sorts of arguments it recognizes as valid.

The relationship between indigenous people and international law points to tension between the law's universal aspirations, and its incapability to overcome what it sees as indigenous particularity and distinctiveness from recognized sovereign states. While the humanism of Vitoria and Las Casas rooted itself in natural law, or Christian faith, today's human right advocates turn to universalism of human rights, as well as democracy and good governance. Human rights discourses appear to include and allow participation of historically excluded indigenous other. However, indigenous peoples cannot participate with their auto-defined identity and language. Universalism in international law continues to connote automatic assimilation or annihilation of the other. As Peruvian novelist and anthropologist Jose Maria Arguedas writes: "How are the barbed wire borders Comandante? How long will they endure? Just as

\footnotetext{
${ }^{80}$ Ibid.

${ }^{81}$ Moses, Ted, "Invoking International Law," in Marie Battiste (ed.), Reclaiming Indigenous Voice and Vision. Vancouver: UBC Press, 2000, p. 175.
} 
those servants of the gods - the gloomy darkness, threats, and terror that were raised up and heightened - are being weakened and worn away, so are these borders, I believe." ${ }^{82}$ The open question is whether the colonial borders of international law are being weakened; whether other speeches can gain presence; for in its original mandate, human rights discourse belongs to the very Leviathan indigenous peoples are trying to oppose.

\section{Conclusion}

The review of human rights discourse in international law and its capacity to empower or subvert indigenous struggles requires a recollection of its colonial past. The purpose of this essay has not been to search for a reform or expansion of international law, which would allow for an inclusion of indigenous voices. The objective instead is to observe the impact of international law's foundations on the current struggles of indigenous peoples within international legal institutions. Indigenous peoples played a role in all periods of international law, as invasion of their lands and population decline gave rise to early canons of the law among nations. The colonial invasion resulted in a massive holocaust, as well as in the creation of international law and sovereign nation states. The violence of this particular historical event never disappeared from the minds of indigenous peoples. It also remained present in the minds of the colonizers themselves who continued to fear the rebel violence that could reverse the colonial order. The existence of indigenous peoples has been recognized, but as potential subversives and never as that of equal actors.

With the emergence of human rights discourse, indigenous peoples become nominally included as participants, but within limits of established discourses and norms. Indigenous peoples continue to struggle for a reform of Eurocentric legal texts, which deny their heritage and knowledge. The international indigenous movement is attempting to provide an alternative view of existing principles and broaden the definitions and cultural reach of human rights. These attempts to 'indigenization' of international law represent for the existing states a new current, which threatens just as the Inkarri myth, to reverse the centuries long period of disorder and confusion initiated by the Europeans.

\footnotetext{
${ }^{82}$ Arguedas, Jose Maria, "Last Diary? August 20, 1969," in The Fox from Up Above and the Fox from Down Below. Pittsburgh: University of Pittsburgh Press, 2000, p. 260.
} 


\section{Bibliography}

\section{Books}

Anaya, James, Indigenous Peoples in International Law. New York and Oxford: Oxford University Press, 1996, p. 36

Anghie, Anthony, "Francisco de Vitoria and the Colonial Origins of International Law," (1996) 5(3) Social and Legal Studies. pp. 321-336.

- Imperialism, Sovereignty and the Making of International Law. Cambridge: Cambridge University Press, 2005, p. 47.

Arguedas, Jose Maria, Yawar Fiesta. Buenos Aires: Editorial Losada, 1941.

Arguedas, Jose Maria y Francisco Izquierdo Rios, Mitos, leyendas y cuentos peruanos. Lima: Ministerio de Educacion, 1947.

Arguedas, Jose Maria, "Himno a Tupac Amaru," in Migel Angel Huaman (ed.), Poesia y utopia andina. Lima: DESCO, 1988, p. 65.

Arguedas, Jose Maria, "Last Diary? August 20, 1969," in The Fox from Up Above and the Fox from Down Below. Pittsburgh: University of Pittsburgh Press, 2000, p. 260.

Casesse, Anthony, Self-Determination of Peoples: A Legal Reappraisal. Cambridge: Cambridge University Press, 1995.

Chakabarty, Dipesh, Habitations of Modernity: Essays in the Wake of Subaltern Studies. Chicago University Press, 2002, p. 28.

Chimini, B.S, "Third World Approaches to International Law: A Manifesto," in Anghie, Anthony et al. (Eds.) The Third World and International Order. Leiden, Boston: Martinus Nijhoff Publishers, 2003, pp. 49-50.

Cojti Cuxil, Demetrio. "Gobernabilidad democratica y derechos indigenas en Guatemala" in Sieder Rachel (ed.), Guatemala after the Peace Accords. University of London, 1998, p. 148.

Derrida, Jacques, "Force of Law: The "Mystical Foundation of Authority"," (1990) 11 Cardozo Law Review. p. 921.

, "Canons and Metonomies: An interview with Jacques Derrida," in Richard Rand (ed.). Logomachia, The Conflict of the Faculties. Lincoln and London: University of Nebraska Press, 1992. 
Cirkovic $\checkmark$ Colonial Foundations in International Law and Indigenous Struggles / 25

De Las Casas, Bartolome. The Tears of the Indias: Being an Historical and True Account of the Cruel Massacres and Slaughters of Above Twenty Millions of Innocent People Committed by the Spaniards in the Islands of the West Indies, Mexico, Peru, Etc. An Eye-witness Account written by B. de Las Casas, translated into English by John Phillips and Published in London in 1656, Baarle-Nassau: SoMa, 1980.

De Sepulveda, Juan Gines, Democrates Segundo o de las Justas causes de la Guerra contra los indios. Edicion critica bilignue, traduccion castellana, por Angel Losada. Madrid, Instituto Francisco de Vitoria, 1951, pp. 38-43.

De Vitoria, Francisco, Political Writings. Cambridge: Cambridge University Press, 1991, pp. 231-352 (3.8.18).

Dobyns, Henry and Doughty Paul, Peru: A Cultural History. New York: Oxford University Press, 1976, p. 122.

Fitzpatrick, Peter, Modernism and the Grounds of Law. Cambridge: Cambridge University Press, 2001, p. 155.

Flores Galindo, Alberto, Buscando un Inka: Identidad y utopia en los Andes. Magdalena: Instituto de Apoyo Agrario, 1987.

Franck, Thomas, Fairness in International Law and Institutions. Oxford: Oxford University Press, 1995.

Furtado, Celso, Economic Development of Latin America: Historical Background and Contemporary Problems, Second Edition, Cambridge: Cambridge University Press, 1978.

Galeano, Eduardo, Memory of Fire, I. Genesis. New York: Norton and Company, 1985.

Gonzalez, Eduardo. "La globalizacion del Derecho a la Verdad," in Memorias en conflicto: Aspectos de la violencia politica contemporanea. Belan, Raynald et al. (Eds.). Lima: IEP, IFEA, 2004.

Hanke, Lewis, All Mankind is One: A Study of the Disputation Between Bartolome de Las Casas and Juan Gines de Sepulveda in 1550 on the Intellectual and Religious Capacity of the American Indians. Northern Illinois University Press, 1974, p. 4.

Kennedy, David, “A New Stream of International Law Scholarship,” (1989) 7(1) Wisconsin International Law Journal. p. 13.

Koskenniemi, Martti, "Hierarchies in International Law: A Sketch,” (1997) 8(4) European Journal of International Law. p. 4.

— The Gentle Civilizer of Nations. Cambridge: Cambridge University Press, 2001.

Koskenniemi, Martti, and Päivi Leino, "Fragmentation of International Law? Postmodern Anxieties," (2002) 15 Leiden Journal of International Law. pp. 353-379. 
Cirkovic $\downarrow$ Colonial Foundations in International Law and Indigenous Struggles / 26

Manuel, George and Micheal Posluns, The Fourth World: An Indian Reality. New York: The Free Press, 1974.

McNeil, Kent, "Reconciliation and the Supreme Court: The Opposing Views of Chief Justices Lamer and McLachlin,” (2003) 2 Indigenous Law Journal. pp.1-25.

Moses, Ted, "Statement by Ambassador Ted Moses on behalf of the indigenous peoples of the North American Region to the World Conference on Human Rights," Vienna, 14-25 June 1993, Available at: http://www.dialoguebetweennations.com.

_ , "Invoking International Law," in Marie Battiste (ed.), Reclaiming Indigenous Voice and Vision. Vancouver: UBC Press, 2000, p. 175.

Munarriz, Gerardo, A Comparative Analysis of the UN and OAS Failures to Positively Affect the Human Rights Situation in Peru. Master of Laws Thesis, North York, Ontario: York University, 2004.

Orford, Anne, “The Gift of Formalism," 15 (2004) European Journal of International Law. p. 188.

Quijano, Anibal, "Coloniality of Power and Eurocentrism in Latin America," (June 2000) 15 (2) International Sociology, pp. 215-232.

Rostworowski de Diez Canseco, Maria, History of the Inca Realm. Cambridge University Press, 1999, pp. 3-4.

St. Thomas Aquinas, On Law Morality and Politics. William P. Baumgarth and Richard J. Regan (Eds.), Indianapolis: Hackett Publishing Company, 1988, pp. 19-20, 58-60.

Thornberry, Patrick, Indigenous Peoples and Human Rights. Manchester: Manchester University Press, 2002, p. 63.

Thornton, Russell, American Indian Holocaust and Survival: A Population History since 1492. Norman: University of Oklahoma Press, 1987.

Youngblood Henderson, James (Sakej), “The Context of the State of Nature," in Marie Battiste (ed.), Reclaiming Indigenous Voice and Vision. Vancouver: UBC Press, 2000, p. 11.

, "Post Colonial Ghost Dancing," in Marie Battiste (ed.), Reclaiming Indigenous Voice and Vision. Vancouver: UBC Press, 2000, p. 169. 


\section{Documents and Cases}

Awas Tigni v. Nicaragua case, the Court Judgment No. 79, the Case of the Mayagna (Sumo) Awas Tingni Community v. Nicaragua of 31 August 2001, Available at: http://www.oas.org.

Charter of the United Nations, 1 United Nations Treaty Series xv1; (1946).

Draft Declaration on the Rights of Indigenous Peoples, Revised Working Paper Submitted by the Chairperson/ Rapporteur, Mrs. Erica-Irene Daes, E/CN.4/Sub.2/1993/26.

International Covenant on Civil and Political Rights (CCPR), (1966) 999, United Nations Treaty Series 171 , in force 3 January 1976.

International Covenant on Economic, Social, and Cultural Rights (CESCR), 993, United Nations Treaty Series 171, in force 23 March 1976.

Universal Declaration of Human Rights, General Assembly Resolution 217 A(iii), Adopted 10 December 1948.

Worcester v. Georgia 31 US 515 (1832). 